\title{
Assessment of Medical Waste Management in Port Sudan Teaching Hospital, Sudan
}

\author{
Tahani Babiker ELya ${ }^{1,2}$, Babiker Ahmed Babiker ${ }^{3}$ \\ ${ }^{1}$ Assistant Professor, Faculty of Public Health and Tropical Medicine, Jazan University, Jazan, Saudi Arabia \\ ${ }^{2}$ Assistant Professor, Faculty of Medicine, Red Sea University, Portsudan, Sudan \\ ${ }^{3}$ Assistant Professor, Faculty of Public Health and Environmental Health, Khartoum University, Khartoum, Sudan
}

\begin{abstract}
This study was conducted in Port Sudan teaching hospital Red sea state, Sudan, in the period from March 2014 to March 2015 as a case study to express the reality of medical solid waste management in the state, where the hospital represent the largest hospitals in the state. The main objective is to assess To assess the management of medical waste in the hospital in terms of the collection, storage, transportation and final disposal and to know the amount and components of medical waste management and to find out the amount of waste produced, the quality and the problems caused by them and finally to propose recommendations to improve the situation. The data were collected by observation check lists to write notes during the field work, interview with the medical staff and structure questionnaire with cleaners to assess their awareness about hazard of medical waste. Quantitative technique also was used. Six field observers have been trained on the various field operations before the field work. The field work implemented in all departments was in all departments of the hospital throughout the twenty-four hours, for four months, where daily work is divided into three shifts in each section. The field work confine in the first phase on observations and taking notes only. The second phase based on control of separation of medical waste from other waste, to identify the amount of medical waste from various sections. The study shows that there is lack of a suitable system for management of the medical waste in hospitals, as well as the lack of knowledge about hazard from medical waste among worker and the lack of proper separation of medical waste from other waste, and there is no infrastructure for that, no pretreatment for the medical waste in the hospital and it disposed in random landfill there is no restricted disposal methods for medical waste. The study recommended that hospital with collaborate with ministry of health should develop clear plans and policies for the proper management and disposal of wastes.
\end{abstract}

Keywords: medical waste management, Port Sudan, Sudan

\section{Introduction}

Biomedical waste management has recently emerged as an issue of major concern not only to hospitals, primary healthcare centers and nursing home authorities but also to the environment $[1,2]$. Advances in medical facilities and the introduction of more sophisticated instruments have increased the waste generated per patient in health-care units worldwide [3]. According to the World Health Organization (WHO),high-income countries generate on Average up to $0.5 \mathrm{~kg}$ of hazardous waste per hospital bed per day. Although the figure for low-income countries is only $0.2 \mathrm{~kg}$ per hospital bed per day, healthcare waste is often not separated into hazardous or non-hazardous wastes, making the real quantity of hazardous waste potentially much higher [4]. Clinical solid waste is a particular challenge in most health-care facilities of the developing world. Poor handling practices and inappropriate disposal of hospital waste is an increasing health hazard in these countries [5-7]. For example, hazardous and medical wastes may be handled and disposed of together with domestic wastes, thus creating a health risk to municipal workers, the general public and the environment [8]. Abd elsalaasl [9], conducted a study at Shendi Hospitals, north Sudan to assessed the medical waste management, in the period from March 2009 to March 2010 , The study shows that there is lack of a suitable system for management of the medical waste in hospitals . Also, Nazik et al [10], conducted a study to Management of hospitals solid waste in Khartoum State, the result indicate that generation rate of medical waste in the studied hospitals was found to be $0.87 \mathrm{~kg} / \mathrm{day}$, which lies within the range for the low-income countries. In Port Sudan there is no relevant published studies related medical waste management in Red sea state. The objective of this study therefore was to analyze the current status of medical waste management in Port Sudan, the largest city in Red sea state , and to identify and evaluate of generation, collection, on-site handling, storage, transportation and safe disposal of medical waste through interviews made to waste workers.

\section{Methods \& Materials}

\section{Study design}

This experimental study was carried out in Port Sudan teaching hospital, Red sea state, Eastern Sudan, from 20142015.

\section{Data collection}

The data gathered were based upon experiments, questionnaire, and checklists to write notes during the field work and interview with the medical manger for each unit. Questionnaire was designed to health waste worker, which includes information about age, educational level of workers, working year duration, injury during work and occupational health and safety procedures. Also the quantity of the waste was determined in each section by using a portable crane scale. Colored plastic bags were distributed to supervisors and waste workers to collect and segregate waste according to waste type in each unit during the three shifts per day. The collection of clinical waste sample was carried in the period (May-July 2015) 


\section{International Journal of Science and Research (IJSR) \\ ISSN (Online): 2319-7064 \\ Index Copernicus Value (2013): 6.14 | Impact Factor (2015): 6.391}

\section{Data analysis}

The quantities of hospital wastes were presented in terms of $\mathrm{kg} \backslash$ day for the total amount of waste generation. The figure obtained was then divided by the total number of beds (160 beds), to estimate the quantity of medical waste generated per bed per day in hospital. The data gathered from the questionnaire were compiled by a computer and were analyzed using (SPSS).

\section{Results}

\section{Result of observation}

Segregation of sharps: Sharps, Needles and syringes disposed together with general waste. Needles were discarded in multi-used containers without disconnecting the needle from the syringe and sometime found in tables of nursing.

Although there are waste containers in most units the study found that some waste scattered in ground area. Human body parts and placentas generated in operation theatres segregated and usually given to co-patients to be buried, Radioactive, liquid pharmaceutical and chemical wastes were poured into the sewage in hospital All HCFs fail to maintain the segregation along the waste stream due to the absence of specific collection and disposal services for hazardous health care waste( $\mathrm{HCW}$ ). Labeling of hazardous waste types was completely absent. Most of workers used their naked hands in handling the waste bag to the main metal container of the hospitals.

The off-site waste transportation from the hospital was done by the Red sea municipality at the end of each shift at $8: 00 \mathrm{am}, 4: 00 \mathrm{pm}$ and $12: 00 \mathrm{pm}$ and was carried manually to vehicles, the medical waste were transported daily by covering trucks or pickups.

No incinerator for medical waste in the hospital and hospital disposed of their waste at the same site as the municipal waste (Port Sudan landfills) located about $20 \mathrm{~km}$ away from the city. All hospital personnel were not trained about handling and management of medical wastes, infection control and protection against medical waste hazards.

\section{Result of questionnaire}

Table (1): Explain (87\%) of health care waste worker were illiterate, $(58 \%)$ of them their experienced over 8 years, only $(10 \%)$ had get a medical examination before employment, $4 \%$ of workers were immunized before joining the job and about $27 \%$ of workers had an injury during work, most of worker take 8 hour in working and only $13 \%$ had Personal protective equipment. Table (2) (3): Show that the total amount of waste generation rate in all hospital was 91.31 $\mathrm{kg} \backslash$ day and the average of waste generation rate per bed per day was estimated to be $0.6 \mathrm{~kg} \backslash$ bed $\backslash$ day.
Table 1: Distribution of health care waste workers, according to occupational health and safety procedures

\begin{tabular}{|c|c|c|}
\hline Characteristics & Number & Percentage \\
\hline Education level & & \\
\hline Illiterate & 45 & 87 \\
\hline Educated & 7 & 13 \\
\hline Experiences & & \\
\hline 1-3 years & 14 & 27 \\
\hline $4-7$ years & 8 & 15 \\
\hline More 8 years & 30 & 58 \\
\hline Medical examination & & \\
\hline Pre-medical & 5 & 10 \\
\hline Haven't & 47 & 90 \\
\hline Vaccination & & \\
\hline Yes & 2 & 4 \\
\hline No & 50 & 96 \\
\hline injury during work & & \\
\hline Yes & 14 & 27 \\
\hline No & 38 & 73 \\
\hline Work duration & & \\
\hline 8 hours & 42 & 81 \\
\hline More than 8 hour & 10 & 19 \\
\hline Availability PPE & & \\
\hline Yes & 7 & 13 \\
\hline No & 45 & 87 \\
\hline Total & 52 & 100 \\
\hline
\end{tabular}

Table 2: The average quantities of medical waste per week per kg

\begin{tabular}{|c|c|c|}
\hline Units & General waste & Medical waste \\
\hline Obstetric & 150 & 58.2 \\
\hline Pediatric & 135 & 48.1 \\
\hline Surgery & 160 & 55 \\
\hline Medicine & 145 & 39.2 \\
\hline Emergency & 60 & 37 \\
\hline Special for surgery & 80 & 35.8 \\
\hline Radiation & 20 & 11.3 \\
\hline Labs & 70 & 28.1 \\
\hline Renal center & 22 & 300 \\
\hline Kafetria & 280 & 0 \\
\hline Pharmacy & 21 & 11.2 \\
\hline Blood bank & 29 & 14.7 \\
\hline Total & 1172 & 650.6 \\
\hline
\end{tabular}

Table 3: The average quantities of medical waste per day

\begin{tabular}{|c|c|}
\hline Units & Medical \\
\hline Obstetric & 8.3 \\
\hline Pediatric & 6.9 \\
\hline Surgery & 7.9 \\
\hline Medicine & 5.6 \\
\hline Emergency & 5.3 \\
\hline Special for surgery & 5.11 \\
\hline Radiation & 1.6 \\
\hline Labs & 4 \\
\hline Renal center & 42.9 \\
\hline Kafetria & 0 \\
\hline Pharmacy & 1.6 \\
\hline Blood bank & 2.1 \\
\hline Total & 91.31 \\
\hline
\end{tabular}

\section{Discussion}

The study revealed that $87 \%$ of workers were illiterate, therefore all workers are in great risk and exposing to accompanied and also the interview revealed that there is no effective programs for training but they advices their 


\section{International Journal of Science and Research (IJSR) \\ ISSN (Online): 2319-7064}

Index Copernicus Value (2013): 6.14 | Impact Factor (2015): 6.391

workers during work and this disagree with [11] training is intended to make management plan effective and training in health and safety should ensure that workers know of and understand the potential risks associated with health care waste.

$90 \%$ of workers were not subjected to pre medical examination and from interview there is no programmer for medical examination, this disagree with[12] it is unacceptable of health care to ignore the health of its own employees, even when it is not legal obligation, many hospital and other health care facilities operate comprehensives staff health programmers ,providing medical examination on entry. $96 \%$ of workers had not vaccine before employment and from interview there is no clearly programme for immunization, this disagree with [13] viral hepatitis B infection have reported among health care personnel and waste handlers and immunization against HB, tetanus recommended for all personnel handling waste. The results revealed that $27 \%$ of workers had an injury during work and this agree with[14] accidental a needle stick injuries are an occupational hazard for healthcare waste workers, according to the WHO Hepatitis C,B and HIV may have occurred among health care workers through their exposure to a needle stick injuries. The medical waste was carried to temporary storage site manually, this supported by [15].

Personal protective equipment such as heavy duty glove, apron or overall and boots are not systematically available only $30 \%$ of the hospital survey provide waste workers with (PPE) and also during observation found some worker handling the waste by naked hand, this disagree with [11] recommended that all health care waste workers should wear clothing include, overall, industrial standard aprons, gloves, leg protectors, strong boots, safety glasses and face mask. This study revealed that all medical waste is stored in the same containers as domestic wastes, thus increase the volume of waste this result agree with who said that healthcare waste is often not separated into hazardous or non-hazardous wastes, making the real quantity of hazardous waste potentially much higher [4].The study showed that the average rate of medical waste in hospital is $0.6 \mathrm{~kg} \backslash$ bed $\backslash$ day is in corresponded with WHO guidelines(the world Health Organization estimated the total medical waste per person per year is anywhere to be from 0.50 to $3.00 \mathrm{~kg} \backslash$ bed $\backslash$ day in developing and less developed countries[16].

\section{Conclusion}

There was poor knowledge about medical waste risks and safe handling procedures among waste workers and most of units in hospital were not differentiating between domestic and medical waste. Budgets were not allocated for waste management purposes, which caused shortages in waste facilities handling equipment and supplies and the absence of training program for staff, resulting in poor knowledge and practices of waste workers, high rate of injuries and possible exposure of staff and visitors to hazard waste.

\section{Recommendation}

The hospital with collaborate with ministry of health should develop clear plans and policies for the proper management and disposal of wastes. They need to be integrated into routine employee training, continuing education, and management evaluation processes for systems and personnel. It is important to point out that all hospitals in the study area promote the final disposal of the domestic wastes in open dumpsites, representing serious sanitary, environmental and social problems. Further studies assessing health care workers actual and felt needs in relevant areas.

\section{Acknowledgments}

We would like to thanks students in Academic of Health Science department of Public Health in Port Sudan for the assistance and their active collaboration during the research period.

\section{References}

[1] Mandal SK, Dutta J. Integrated bio-medical waste management plan for Patna city, Institute of Town Planners, India Journal, 6(2):1-252,009.

[2] Alagoz AZ, Kocasoy G. Improvement and modification of the routing system for the health-care waste collection and transportation in Istanbul. Waste Management, 28:1461-1471,2008.

[3] Radha KV, Kalaivani K, Lavanya R. A case study of biomedical waste management in hospitals. Global Journal of Health Science, 1:82-88,2009.

[4] Waste from health-care activities. Fact sheet No. 253, November 2011. World Health Organization [online factsheet]

(http://www.who.int/mediacentre/factsheets/fs253/en/, accessed 27 December 2013).

[5] Hossain MS et al. Clinical solid waste management practices and its impact on human health and environment - a review. Waste Management, 31:754$766,2011$.

[6] Mato RR, Kassenga GR.A study on problems of medical solid wastes in Dar es Salaam and their remedial measures. Resources, Conservation and Recycling, 21:1-16,1997.

[7] Nemathaga F, Maringa S, Chimuka L. Hospital solid waste management practices in Limpopo Province, South Africa: a case study of two hospitals. Waste Management, ,28:1236-1245,2008.

[8] Da Silva CE et al. Medical wastes management in the south of Brazil. Waste Management, 25:600-605,2005.

[9] Abd Elsaalam.. Study of Medical Waste Management In Shendi Hospitals, Journal of Shandi university, ISSN:1858-571X,163-192,2011.

[10]Nazik Omer et al , Assessment of medical waste management in Khartoum state hospital,Journal, Journal of Applied and Industrial Sciences, 2014,2(4):201-205.

[11] WHO, 2002, Environmental Health, Regional Office for the Eastern Mediterranean (EMRO), Amman, Jordan.

[12]P. Meers, M. Mc person and J.sedgwick..Infection control in health care. United kingdom ,2ed, 1996. 


\section{International Journal of Science and Research (IJSR) \\ ISSN (Online): 2319-7064}

Index Copernicus Value (2013): 6.14 | Impact Factor (2015): 6.391

[13] Prüss, A, Giroult, E, Rushbrook, P 1999, safe management of waste from health-care activities, Department of Protection of the Human Environment, WHO Graphics, Hong Kong, 98/12312-Bestset/Speedflex-7000

[14] Irfan sencan, Idris Sahin,Mustafayildirim and Nuray yesildal, Unrecognized abrasions and occupational exposures to blood -borne pathogen among health care workers in Turkey. occupational medicine.54:202-206, 2004.

[15] Moshseni,A. Evaluation of medical waste collection, transportation and disposal in public and private hospitals in Mazandaran province.J.Mazandaran.U.Med.Sci,11:45-52,2003. 